\title{
Sigrid af Forselles and The Development of the Human Soul
}

\author{
DOI: https://doi.org/10.30664/ar.98058
}

(c)(Attribution 4.0 International (CC BY 4.0)

$\mathrm{T}$ he five-part relief series The Development of the Human Soul (c.1887-1903) by the Finnish sculptor Sigrid af Forselles is a monumental work consisting of five large plaster reliefs. The artist's esoteric interests have been noted in previous research, but their impact on her art has not been properly analysed. The first part of the relief series, which has for its subject a theme from Scandinavian mythology, belongs to the collections of the Finnish National Gallery, while the other parts, with seemingly Christian content, are situated in the Kallio Church in Helsinki. The separation of the parts and the apparent inconsistency in the thematic structure of the series has caused confusion among those who have attempted to interpret it as a whole, although occasionally a possible Theosophical inspiration has been suggested. This article presents the first attempt at a more profound, esoteric interpretation of the series, arguing that its main theme is a spiritual evolution that attaches itself to the idea of progress and liberation through art. The narrative evolves from materiality and physical strength towards spirituality and immateriality.

'It seems clear that she is a very profound and spiritual person, whose thoughts often dwell in the invisible world, the realm of the spirit, because from there she finds nearly all of her subjects.' (Friberg 1912) ${ }^{1}$

1 Translated by the author from the original Finnish: 'Kaikesta päättäen on hän hyvin

\section{Introduction}

Even though Sigrid af Forselles (18601935) was among the first women sculptors in Finland, and the very first one to have had a full professional career in a field that at the time was generally considered unsuitable for women, she has not exactly become a household name in Finnish art history. She is mainly remembered as a student of Auguste Rodin in whose Paris studio she worked for a few years in the 1880s. Before setting off for the French capital, af Forselles had studied at the Finnish Art Society's Drawing School in Helsinki, as well as receiving some private tutoring from the sculptor Robert Stigell (Konttinen 2004; Lindgren 2006: 46; Westermarck 1937: 121-2). At the Drawing School af Forselles befriended many other women artists of her generation, including Helena Westermarck, who later became an active supporter of her artistic career, and also her first biographer. Westermarck's book on three Finnish women artists Fanny Churberg, Maria Wiik, and Sigrid af Forselles - which came out in 1937, remains

syvämietteinen ja henkevä ihminen, jonka ajatukset usein liikkuvat näkymättömässä maailmassa, hengen valtakunnassa, sillä sieltä hän valitsee miltei kaikki aiheensakin.' 
an essential source of information on the life of the enigmatic sculptor. Westermarck explains that even before her arrival in Paris, af Forselles had set her mind on becoming a sculptor. She enrolled into the Académie Julian where she studied life drawing for two years (Westermarck 1937: 121-2). The Académie did not offer any teaching in sculpture for women, so in 1882 af Forselles joined a private studio rented by Camille Claudel on Rue Notre-Dame-desChamps where a group of aspiring women sculptors worked under the guidance of the French sculptor Alfred Boucher. Before travelling to Italy in 1883 , Boucher asked his friend Rodin to take his place in guiding the young women. Both Claudel and af Forselles, together with the Englishwoman Jessie Lipscomb, who had joined Claudel's studio in 1884, assisted Rodin in the modelling of the human figures for The Burghers of Calais (Les Bourgeois de Calais, 1884-9). In Rodin's studio af Forselles befriended the master's French assistant Madeleine Jouvray who was to become her close companion for many years (Huet 2016: 15, 30; Lindgren 2015: 143-4; AyralClause 2002: 28-56). Apparently Rodin was happy with af Forselles's work because she asked her to continue as his assistant for another monumental sculpture that he was in the process of creating; The Gates of Hell (La Porte de l'Enfer, 1880-1917). However, af Forselles declined. She probably did not think that she could learn anything new from it and, besides, she needed more time and energy to focus on her own career. Before af Forselles left Rodin's studio, she received the master's approval of sketches for a series of large reliefs (Konttinen 2004; Lindgren 2015: 143-4; Westermarck 1937: 125).

In 1887 af Forselles moved to Florence together with Jouvray and rented a studio where she started the process of creating what was to become her magnum opus, the

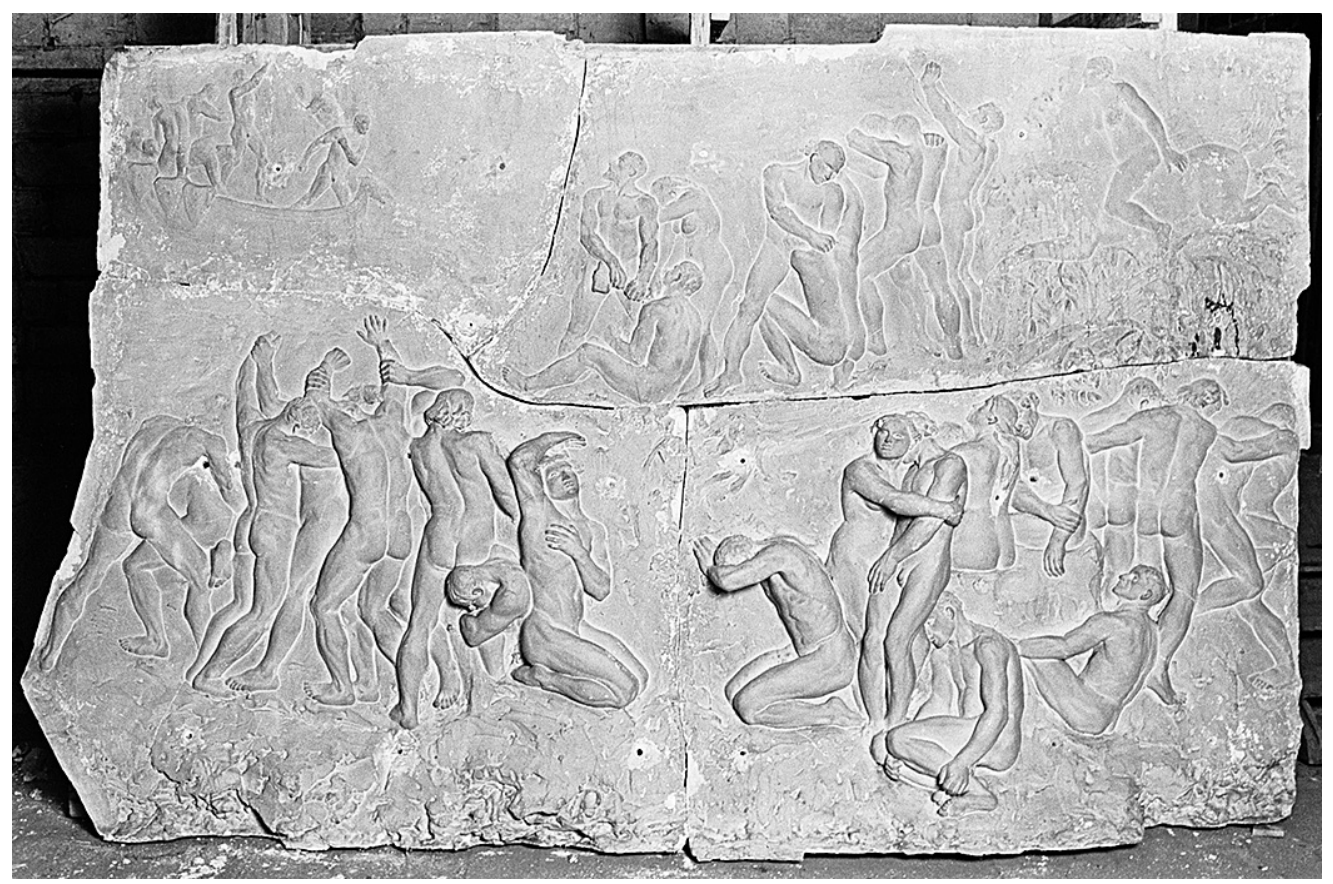

Sigrid af Forselles, The Battle of Men, Motif from Edda, Ragnarök, plaster relief, 195× 256 .

Ateneum Art Museum / Finnish National Gallery, Helsinki. Photo: Finnish National Gallery. 


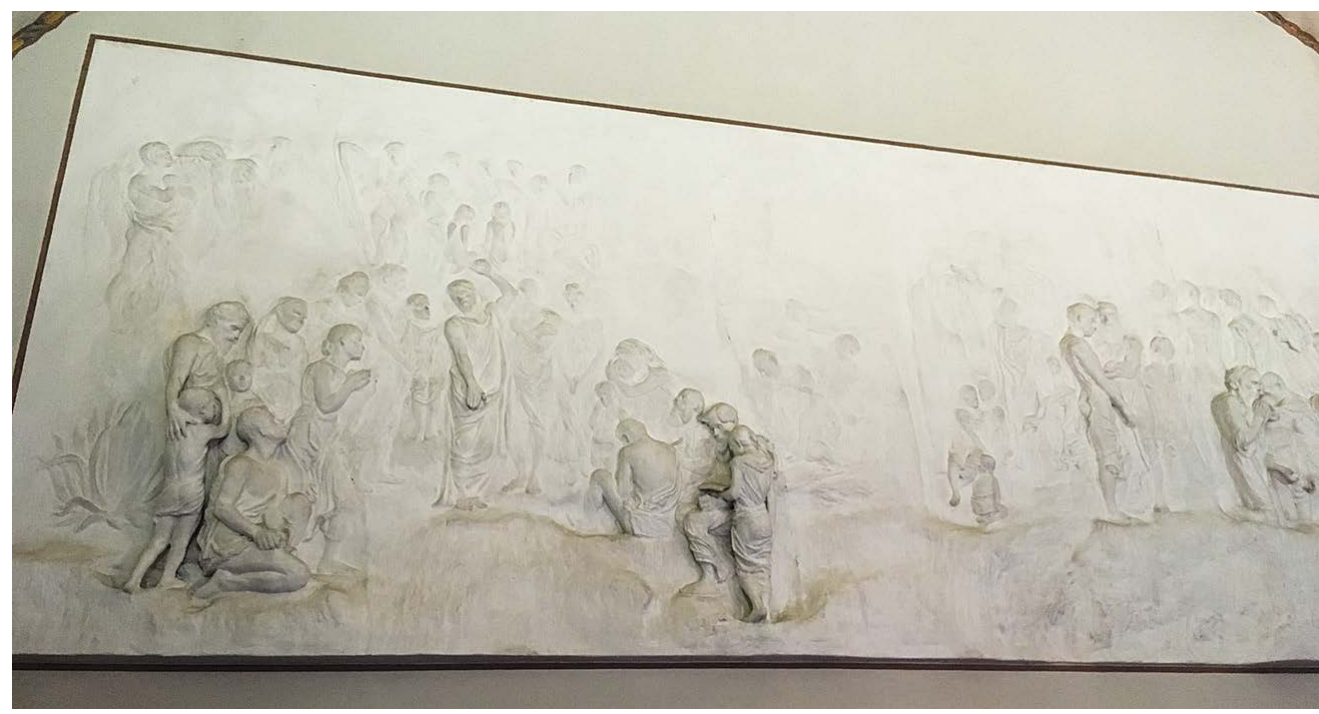

Reliefs by Sigrid af Forselles in the vestibule of Kallio Church. The Sermon on the Mount is on the left and a part of The Babylonian Captivity can be seen on the right. Photo: Marja Lahelma.

relief cycle known as The Development of the Human Soul. Interestingly, af Forselles drew inspiration from the very same work that had given spark to Rodin's Gates of Hell: Lorenzo Ghiberti's Gates of Paradise, a pair of fifteenth-century bronze doors at the Baptistery of St John in Florence (Westermarck 1937: 126-7). Sigrid af Forselles worked on her reliefs for more than a decade, first in Florence and then continuing in Paris. What resulted was a monumental work of art that has caused a fair amount of confusion and hesitancy among those who have attempted to interpret it. The series consists of five individual plaster reliefs, circa $200 \times 250 \mathrm{~cm}$ in size, each presenting a significant turning point in the history of humankind and its spiritual development: 1 . The Struggle (of Humanity) (Människornas kamp / La Lutte), 2. The Captivity (Fångenskapen / La Captivité), 3. The Sermon on the Mount / The Acceptance of Christianity (Bergspredikan / L'Acceptation du Christianisme), 4. The Homeward Journey (Hemfärden / La Retour au Foyer), and 5. The
Arrival Home (Hemkomsten / L'Arrivée au Foyer).

The artist's ambition is revealed in the scope of the work - both in the material and spiritual sense. From her letters it becomes evident that she planned to cast the reliefs in bronze, but despite her wishes this never happened (see Kihlman 2018: 115-21; Lindgren 2006: 55). The first of the plaster casts was purchased by the Finnish National Gallery in 1908, while the other four were placed in the Kallio Church in Helsinki, designed by the Finnish Art Nouveau architect Lars Sonck and built between 1908 and 1912. The separation of the parts of the series and their installation in different rooms in the church makes it impossible for today's audiences to appreciate the grandiose narrative structure of the whole as it was intended. Yet, despite having had the luxury of seeing the entire series exhibited in Helsinki in 1908, the critic Sigurd Frosterus was baffled: perhaps there was an 'open sesame', a kind of password for understanding the series? There had to be something that would 
explain the compositional details and stylistic execution that seemed peculiar in Frosterus's eyes, but he did not know how to look for clues. He did, however, recognise the connections to Italian Renaissance sculpture, and he also mentioned the Danish painter Joakim Skovgaard who was known for religiously themed paintings that were open to esoteric interpretations (Frosterus 1908).

Early on many critics acknowledged that the intended meaning of The Development of the Human Soul must somehow be connected to the artist's esoteric interests, and this notion has regularly been repeated by later commentators. Nevertheless, a full account of the whole series from an esoteric perspective has so far not been carried out. At least to some extent, this is to do with the fact that anything associated with esotericism has tended to have an aura of suspiciousness and, hence, this kind of contextualisation always holds the potential for further marginalising the artist. In her 1937 biography, Westermarck wrote briefly about late nineteenth-century artists' involvement with occultism and Spiritualism, remarking that in Paris af Forselles also came into contact with such phenomena. According to Westermarck this had a profound effect on her friend's outlook on life (Westermarck 1937: 134-5). In spite of this, Westermarck did not seem to think that esotericism had any significant role in af Forselles's artistic production. However, my conviction, and the motivation behind this article, is that late nineteenth-century esotericism is the precise framework that makes af Forselles's relief series meaningful and gives it broader significance. This fascinating and highly ambitious sculptural cycle therefore deserves to be taken seriously as a complex spiritual artwork that was inspired by esoteric thought.
The purpose of this article is to establish a more clearly defined esoteric context for the series and to suggest an interpretation within this framework. It must be pointed out that this is not an easy task, because information about the artist is scarce. Furthermore, there is nothing suggesting that af Forselles was ever a fully committed member of any particular esoteric movement or group. She drew from different religious and cultural sources, committing to nothing but her own personal vision and the quest for truth. In this sense, she quite perfectly fits the definition of the seeker as it has been described by Nina Kokkinen (see her article in this issue). It is therefore quite understandable that scholars have hesitated in making their interpretations. The kind of mixing and matching of esoteric, religious, scientific, literary, and artistic impulses that is typical for seeker-artists makes it difficult to identify exact sources and to draw a clear line between artistic and esoteric activities. However, this is also what makes this kind of artistic attitude so intriguing and worthy of serious examination. In addition to providing knowledge of a particular work of art, the analysis that is carried out within this article can also open up new perspectives onto the cultural milieu of the period and the many ways that artists responded to it, and interacted within it.

The research that I have carried out for this article consists of a careful reading of the literary material on af Forselles that is available (most importantly, Lindgren 2006, 2015; Kihlman 2018; Konttinen 2004, 2008; Westermarck 1937). In addition, I have also consulted the collection of letters from af Forselles to Westermarck that is kept in the archives of Åbo Akademi University. While the amount of material as such is not insignificant (c.16o pieces in total), it mostly consists of postcards and 
short notes, often undated, and containing little or no information regarding the artist's esoteric interests. Hence, in this article I have chosen to focus mainly on two aspects: 1) establishing a more clearly defined context for the reliefs, and 2) examining them against that background. Even art historians often fail to recognise the full potential of works of art as research material and tend to focus more on literary or archival sources. Of course, these are all equally important elements in historical research, but when the amount of available material is limited, contextualisation and close reading of artworks can provide important insight. This article constitutes a step in that direction.

I will argue, first of all, that the main theme of the series is a spiritual evolution that attaches itself to the idea of progress and liberation through art. This idea should be understood in a specific esoteric sense. Secondly, I hope to provide some insight into the mechanisms of inclusion and exclusion that are at work in the narratives of Finnish art and that have pushed af Forselles and her work onto the margins. As a conclusion of sorts, I will discuss the relief series as an 'impossible masterpiece', a conceptualisation that I have adapted from Hans Belting (2001; see also Lahelma 2014: 237-40). It refers to the idea of a total work of art that sets out to provide answers to the most fundamental issues of human existence, but its proportions become so extensive and its purpose so elevated that in the end it is bound to fail in one way or another. I shall offer a brief analysis of the relief series in juxtaposition to another ambitious sculptural work that, in my opinion, falls into the same category - Rodin's Gates of Hell.

\section{The art-historical context}

While Sigrid af Forselles has been to a large extent excluded from the canon of Finnish art, the work that has received most attention from scholars of art history is The Development of the Human Soul. Most recently, Asta Kihlman has examined it in her doctoral dissertation (2018) from the perspectives of gender and identity politics. She presents a detailed investigation of the discussions that circulated the work and the historical processes that determined its fate, which is quite interesting in regard to the mechanics of marginalisation. There is no doubt that the artist herself considered the relief her most important work and had high hopes for having it cast in bronze and displayed in some prestigious setting (Kihlman 2018: 115-21). Individual parts of the series were exhibited at Salon du Champ de Mars in Paris between the years 1901 and 1903 , by which time the whole series had been completed in the form of plaster casts. In 1901, after the first two parts had been shown in Paris, af Forselles was invited - the first Finnish woman to receive such an invitation - to become an associée of the Société des Artistes Français (Westermarck 1937: 135).

Since no interested buyers emerged in Paris, all five reliefs were eventually shipped to Finland where they were put on display in Helsinki at the Women Artists' II Exhibition in 1908. Previously, there had been discussions about finding a place for the reliefs in the Turku Art Museum (established in 1904), but the negotiations, in which Westermarck was actively involved, came to nothing. Westermarck also tried to offer the whole series to be purchased by the Finnish National Gallery, but in both cases the reasons why no acquisition was made in the end were to do with the high price of the series which af Forselles was then still hoping to cast in 
bronze (at the buyer's expense), as well as the fact that the reliefs remained in Paris, and it was therefore not possible for the potential buyer to see them (Kihlman 2018: 117-18).

After the 1908 exhibition, only the first part, which has for its subject Scandinavian mythology, was purchased by the Finnish National Gallery, while the remaining four parts, which have been interpreted as having Christian content, finally, as a result of Westermarck's active campaigning, found a place in the Kallio Church. The fact that the first part has been separated from the rest is symptomatic of af Forselles's marginalisation, and has made the task of interpretation exceedingly complicated. When the first part is removed, it is possible to understand the content of the four remaining pieces in Christian terms, especially when they are displayed in a church. Of course, this goes very much against the artist's intention, and apparently she was not at all pleased with the arrangement. To add a level of confusion, the four parts in the Kallio Church are displayed not only in different rooms, but also in an incorrect order. The Captivity and The Sermon on the Mount are placed together in the vestibule so that they look like one single relief, with the New Testament subject (number 3) on the left hand side, and the Old Testament one (number 2) on the right. The Homeward Journey and The Arrival Home are found in the organ galleries with no public access. Hence, even the four parts of the series placed in the church cannot be viewed as a whole. The first part, which is owned by the Finnish National Gallery has rarely been on display. Due to poor storage conditions it is dirty and badly cracked.

The name of the series was established early on as The Development of the Human Soul (Ihmissielun kehitys / Människoandens utveckling) even though the artist only named the individual parts, and gave no name to the whole series when it was exhibited for the first and last time in Helsinki in 1908. It is therefore not known whether this name comes directly from af Forselles. In her letters, and often also in the press, the work was referred to only as 'the relief series'. According to Westermarck (1937: 127-8), the purpose of the series was to represent 'the development of the human spirit, its progress, and its ultimate liberation.' ${ }^{2}$ Subsequent scholars have for the most part relied on information provided by her. Liisa Lindgren has published articles on af Forselles that provide some very useful further insight. The only attempt at a full interpretation of the relief series has been carried out by Arja Hartikainen in her master's thesis (1994).

Even though Westermarck reflects on her friend's esoteric interests to some extent, she does not actually put this information to use in her description of the relief cycle, which, in spite of being quite detailed, remains on a rather abstract level. She explains, moreover, that like her teacher Rodin, Sigrid af Forselles always remained a realist (Westermarck 1937: 134-5). This insistence probably originates from Westermarck's own artistic ideals and those of the time of publication (see Konttinen 2008: 376). Even though the modelling of the human body in the relief series is close to nature, it would be impossible to grasp its deeper meaning within a realist framework. Moreover, interpretations of Rodin's oeuvre have evolved since Westermarck's days, and the deep spirituality of his art has been acknowledged more fully. A large part of

2 Swedish original: 'Tanken, ur vilken de sprungit fram och som sammanhåller dem, har varit att i mångskiftande bilder framställa historien om människoandens utveckling, framåtskridande och slutliga befrielse.' 


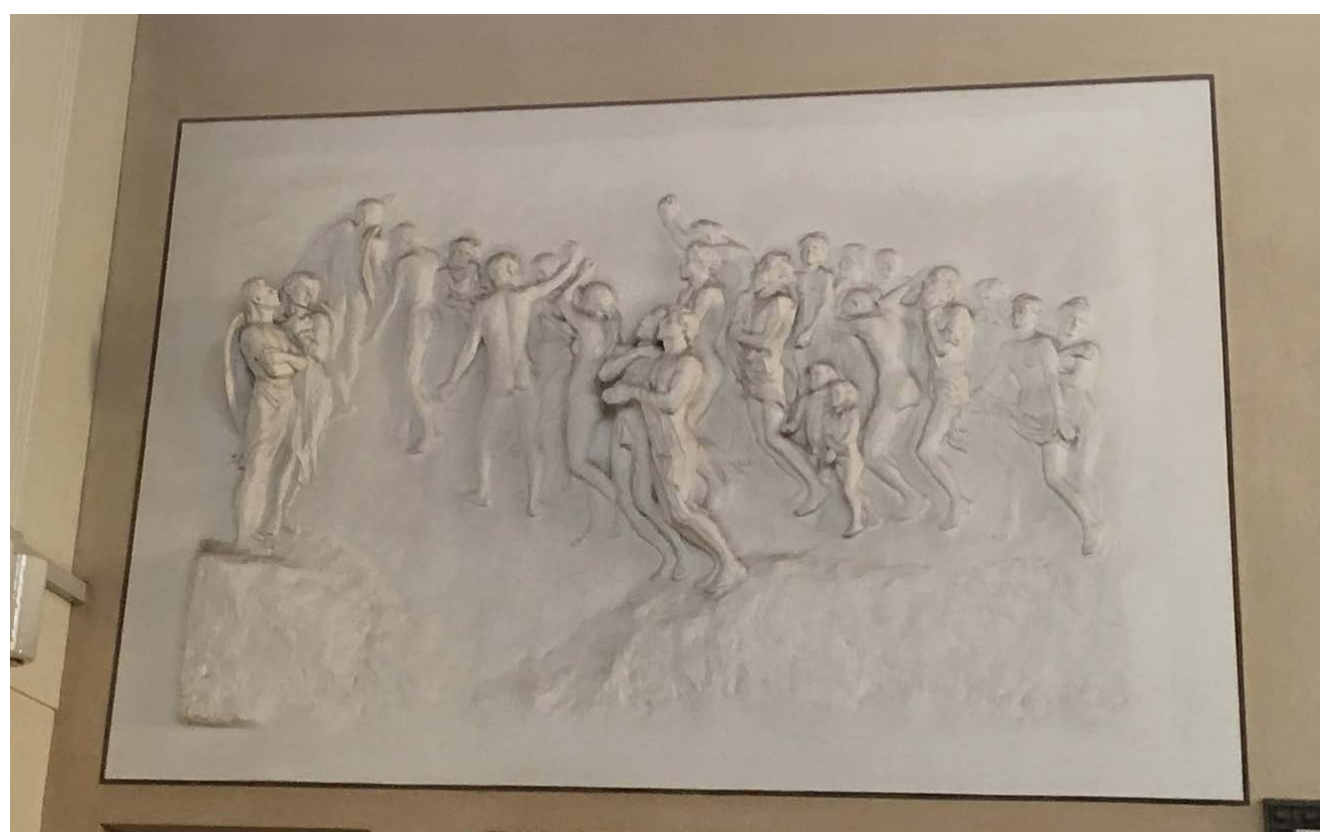

The Homeward Journey, relief by Sigrid af Forselles in the organ gallery of Kallio Church. Photo: Marja Lahelma.

his oeuvre can equally well fall into the Symbolist category and, as his friend Rainer Maria Rilke explained, his 'imitation' of nature was the kind that followed nature's creative force rather than its appearance (Rilke 1903).

The art historian Salme Sarajas-Korte (1966: 76-7) was probably the first to place The Development of the Human Soul firmly within the Symbolist realm, but her extensive study on Finnish Symbolism only mentions the relief series in passing. Lindgren follows Sarajas-Korte's lead, connecting the series to Symbolism, and to the artist's esoteric interests, suggesting that she was a Theosophist (Lindgren 2006: 50-1; 2015: 145). Lindgren comments briefly on the possible meaning of the work, but does not offer a full interpretation. Arja Hartikainen (1994), on the other hand, does attempt to interpret the series as a whole. What is problematic in her approach, however, is that she understands late nineteenth-century esotericism as a vague mysticism based mainly on Neoplatonism and Swedenborgianism in their French interpretations (more or less a simplified version of the model provided by Sarajas-Korte). Hartikainen also mentions Theosophy as a possible source of inspiration for af Forselles, even though according to her, this Theosophical interest is not revealed in her subject matter which remains 'thoroughly Christian'. As Hartikainen understands it, Theosophical subjects would only be those related to Eastern mysticism (Hartikainen 1996: 19). Moreover, she finds it difficult to understand why the first part of the relief series is clearly 'pagan' while the other parts are 'Biblical.' Hartikainen connects the first part vaguely with a Theosophical idea of the common universal truth behind all religions and myths. The choice of a Scandinavian mythological subject is then explained by the artist's Nordic background 
(she was Swedish-speaking and belonged to the Finnish-Swedish cultural sphere) (Hartikainen 1996: 42-3).

Despite being somewhat simplistic and based on a limited understanding of late nineteenth-century esotericism, Hartikainen's approach can nevertheless provide some useful starting points for a more profound interpretation. First of all, she is probably correct in her view that Theosophy might provide a thematic context that ties together all parts of the series. Second, she quite accurately identifies that the fact that the third part depicts the Sermon on the Mount gives a key to the meaning of the work as a whole (Hartikainen 1996: 33). Yet, as I have argued above, it is necessary to find a more precise esoteric framework in order to fully grasp the meaning and purpose of the series.

\section{The esoteric context}

In af Forselles's Parisian surroundings of the 188 os and 1890 s, esoteric ideologies were multifarious and extremely widespread. The French occultist Jules Bois (1894), paints a vibrant picture of the clittle religions' of Paris at the end of the nineteenth century, describing various cults and movements, from the 'last pagans' to Swedenborgians, Buddhists, Theosophists, satanists, gnostics, and so on. It is therefore difficult to point out any exact sources for af Forselles's esoteric thought. Judging by the scant material she left behind, she was not a keen writer of letters, and, at least in what has been preserved, she very rarely mentions anything about her esoteric interests. According to Westermarck (1937: 135), af Forselles only discussed these issues with those people whom she knew would understand. Yet even though Westermarck herself was quite sceptical about all kinds of spiritual matters, at least on a few occasions af Forselles is known to have taken up the subject with her. For instance, in the spring of 1897 , after attending a course on magnetism, af Forselles wrote to Westermarck that she had greatly advanced in her occult studies (Lindgren 2006: 51). From the manner in which she explains it, it can clearly be understood that for af Forselles her esoteric interests were completely intertwined with her artistic practice - and she knew that this irritated many people, 'like a nail in the eye' - but she insisted on following her own path, even if this meant that she was 'ahead of her time' (letter to Westermarck 2.3.1897, Å). ${ }^{3}$ Another fascinating document is a letter written a few years earlier, in which af Forselles tells her friend about the beautiful things she has seen in the 'Spirit World' and her encounters with her spirit guide, 'Brunellesco', referring to the Italian Renaissance sculptor and architect Filippo Brunelleschi:

Brunellesco has showed me an extraordinarily beautiful church in a style that is not yet known on this wretched planet. I am truly worried that in order to bring a new kind of architecture to this earth, he will incarnate himself when I finally arrive at home in the Spirit World. I will surely become so jealous that I will come down with him and work with him. No, would it not always be better to incarnate oneself to a higher planet already now after all these incarnations on the earth. Dear W. do not forget the things I have told

3 Swedish original: 'Mina osculta studier i hvilka jag gått på senare tider mycket framåt $i$, samt min konst hafva alltid varit som en nagel i öga för folk och jag utsätter mig icke mera för obehag. Modet är för mig för vaskligt också dagens smak, jag följer saken själf om det äfven vore före tiden. 
you about the invisible world. (Letter

to Westermarck, undated [received 10.7.1893], Å) ${ }^{4}$

The reference made by af Forselles to cycles of incarnations and the possibility of continuing life in spirit form on another planet is extremely intriguing. The question as to whether there was life on other planets was widely discussed in late nineteenthcentury popular science as well as in esoteric circles. The Swedish philosopher and mystic Emanuel Swedenborg had already, in the eighteenth century, written about life on other planets, and his thoughts were hugely popular in Parisian esoteric and literary circles (see Wilkinson 1996). However, a more direct and contemporary source could be the spiritually inclined French astronomer Camille Flammarion, whose writings enjoyed a great commercial success. In works that represented early science fiction, he propagated modern myths about extraterrestrial life, suggesting that the human soul evolves through cosmic reincarnation.

Flammarion was influenced by the spiritual theories of the Saint-Simonian philosopher Jean Reynaud (Herrick 2008: 57). The Saint-Simonian movement was named after the socialist philosopher,

4 Swedish original: 'Sedan ser jag mycket vackra saker i Andeverlden och Brunellescho har visat mig en utomordentligt vacker kyrka, en styl som visst ännu icke är känd på denna tarfliga planet. Jag är helt rädda att han för att hämta en ny arkitektur till vår jord inkarderar sig, då jag en gång kommer hem till Andeverlden. Jag blir visst så svartsjuk att jag kommer med och arbetar med. Nej vore det alltid bättre att inkarnera sig på en högre planet nu redan efter alla dessa inkarnationer på jorden. K. W. [Kära Westermarck] glöm icke allt hvad jag sagt dig om det osynliga'
Claude Henri de Rouvroy, Comte de SaintSimon, who wanted to re-establish the lost unity of society in union with spiritual life. Although Saint-Simonism has typically been connected mainly to social and political thought, it also had an important spiritual dimension. The movement drew ideas from Freemasonry and employed the language of Catholic Christianity to promote a new kind of religious thought, a kind of Christian Theosophy, based on the notion of spiritual progress that would also advance social change (Faivre 2006: 264; Pilbeam 2013: 25-7). Saint-Simonism also gave support to the liberation of women (Pilbeam 2013: 40), which might have been something to attract af Forselles towards its teachings. Saint-Simonism as such was a movement belonging to the first half of the nineteenth century, but its impact continued throughout the century. At the end of the nineteenth century, currents of thought that combined esoteric ideas with Catholicism were widespread, and some movements associated the liberation of women with the notion of spiritual progress. Westermarck was an active feminist, and it is entirely possible that the two friends shared this ideology, if not its spiritual aspect.

Perhaps something about af Forselles's interests and activities could also be uncovered through the people she is known to have socialised with. Her fascinating personality and unusual artistic talent did not go unrecognised by the young Finnish artist Magnus Enckell, who became infatuated with both af Forselles and her companion Jouvray. He described af Forselles's art as simple and beautiful like music; it was art of the future, and it would probably take generations before people would fully comprehend its greatness. $\mathrm{He}$ also explained to his friend, the philosopher Yrjö Hirn, that it represented a kind of 
'feminine aesthetic'; it was not 'women's art' in any sense that might in the context of the time be understood as negative, but 'feminine' in a very positive sense, representing something new and different (SarajasKorte 1966: 76-7, 189). Enckell was one of the few Finnish artists who openly talked about their fascination with the ideas promoted by the influential figure Joséphin Péladan, the organiser of Rosicrucian art salons, who combined esoteric ideas with Symbolism and an admiration for Italian Renaissance art (Sarajas-Korte 1966: 84). Péladan had founded in 1888 an esoteric brotherhood called 'Ordre Cabbalistique de la Rose+Croix' together with the occultist Stanislas de Guaita, but he soon fell into conflict with the anti-Catholic views of Guaita and the rest of the group, and went on to form a separate group in 1892 which he called 'Ordre de la Rose+Croix Catholique du Temple et du Graal'. The same year he organised the first art salon (Salon de la Rose+Croix) at DurandRuel's gallery. These salons were organised annually until 1897 , and particularly at the beginning they received a lot of attention - positive as well as negative (see Churton 2016: 377-95; Pincus-Witten 1968).

Péladan's ideals appear in certain ways to be quite similar to those of af Forselles, and this connection perhaps could provide some background for her archaistic tendencies and admiration for Italian Renaissance art. Péladan was opposed to realism and naturalism, but for him content was more important than style and, in fact, many of the artists who exhibited in his salons were in stylistic terms quite close to naturalism. What Péladan did not approve of in naturalist art was not the style but the trivial subject matter. For him the subject in itself was a symbol, and therefore certain subjects were entirely banned from his salon; for example, scenes of contemporary life, scenes of country life and landscapes, except in the style of Poussin. Subjects that were welcomed included Catholic dogma, Eastern religions (except for those of the 'yellow races'), allegory, the sublimated nude, and the expressive head in the style of Leonardo and Michelangelo (for the rules of Péladan's salon, see Pincus-Witten 1968: 211-16). The Development of the Human Soul certainly would have fit Péladan's criteria had it not been executed by a woman. Péladan did not accept any works by women into his salons. Many women did, however, visit the salons. The Finnish artist Beda Stjernschantz, who was acquainted with Forselles and Jouvray through their mutual friend, Enckell, was impressed if also a little bewildered by a visit to the first Salon de la Rose+Croix in 1892, on the day of its vernissage, writing home that she had seen some wonderful things but also a few works that were incomprehensible or just plain crazy. She also paid attention to the eccentric appearance of Péladan's followers, who had long hair and wore purple cloaks with ruffles (Sarajas-Korte 1966: 88).

\section{The development of the human soul}

While the esoteric currents described above say something about the Parisian intellectual context in which af Forselles created her reliefs, they do not yet offer exact tools for deciphering the meaning of the series. It is clear that af Forselles drew from Christianity but blended it with esoteric impulses, which was by no means an unusual combination in the late nineteenthcentury cultural context. The widespread revival of Renaissance art, exemplified above by Péladan's circles, but also reflected elsewhere in the culture of the period, rode on the back of a revival of Renaissance thought, including, for instance, the hermetic philosophy of Marcilio Ficino. For Ficino, who always remained convinced 
of his Christian faith, Jesus Christ was the exemplar of human spiritual fulfilment. Ficino gave a central role to the human soul in his hierarchically presented cosmological vision, believing that through meditation the soul could detach itself from the restraints of materiality and enter the spiritual realm. He presented this as a journey towards a higher degree of being that culminates in the direct knowledge and vision of God (Goodrick-Clarke 2008: 38-40). Ficino's description corresponds quite closely to the idea of a progressive journey of the human soul that is presented in af Forselles's relief cycle. However, for a closer reading of the individual parts of the series, I have employed one particular esoteric text as my guide: The Great Initiates by Edouard Schuré (1888). Schurés Theosophically inspired book provides a visually stimulating description of the gradual spiritual enlightenment of humanity through a chain of individuals initiated into the secret doctrine. Schurés book was extremely popular among artists in particular. Hence, in what follows, I have drawn mainly from Schuré, but it should be kept in mind that af Forselles may very well have found similar ideas elsewhere.

Above, I have already suggested that the relief depicting a scene from the Sermon on the Mount should be perceived as the key to the meaning of the whole series. Its central figure, Jesus, is presented by Schuré as the last of the 'great initiates' and as the one through whom the secret doctrine is made available for all humanity. Schurés study is also a history of the 'white race' that has come to the leadership of civilisation after a succession of other races that preceded it and were also mixed with it. This is obviously a problematic concept in today's context. Yet it may provide some background for the relief series that is also known under the name The History of the
Human Race. Hartikainen (1994: 2) deems this title unsuitable because in her view the series as a whole clearly represents an allegory of spiritual development rather than a description of the historical phases of humanity. However, within an esoteric context these two are parallel - the spiritual development of an individual soul corresponds to the liberation of the whole of humanity. Hence, the series as a totality can be seen to represent a gradual unfolding of the spirit in the soul of the individual as well as through the human race. In The Great Initiates the current civilisation, which is the one that will bring all humanity to liberation, is described as the white or Aryan race that has its origins in the forests of northern Europe. Schuré was a great admirer of Wagner, and through his works he had also become interested in Scandinavian mythologies. He was an editor of the Parisian journal Révue Wagnerienne, and had established himself as a leading Wagner expert in France with the two-part publication Le drame musical: Richard Wagner, son oeuvre et son idée (1875). Through the widespread enthusiasm for Wagner, Scandinavian mythologies were popularised among the French intelligentsia (see Fauser 2008).

The founder of the Theosophical Society, Helena Petrovna Blavatsky, also often referred to Scandinavian mythology - and she was by no means the only one in the late nineteenth-century context to provide metaphysical interpretations of myths. Theosophy in general opened innovative ways for Westerners to internalise all kinds of non-Christian belief systems (often associated with Buddhism and other Eastern religions, but this was not always the case). In addition, Theosophy also provided new interpretations of Christian content. In a more elaborate Theosophical framework, it is possible to perceive the Scandinavian 


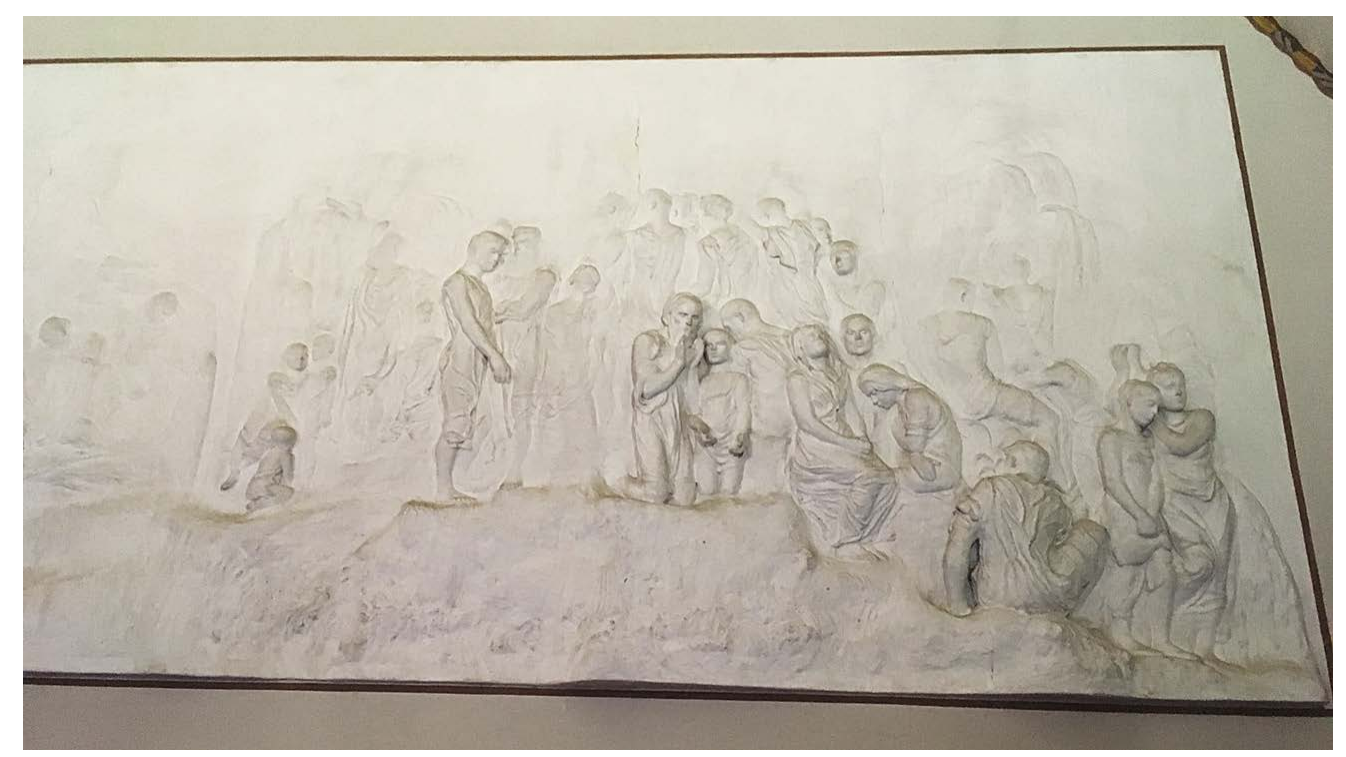

The relief Babylonian Captivity by Sigrid af Forselles in the vestibule of Kallio Church.

Photo: Marja Lahelma.

theme in af Forselles's relief as a reference to the northern origin of human civilisation. According to Schuré (and Blavatsky) the origins of the current race of humanity (the white race/the fifth root race/the Aryans) was in the cold forests of northern Europe, and it was the task of this race to elevate mankind from the prison of materialism and lead it back to the more spiritual planes. This metaphysical interpretation also gave a specific meaning for Thor's magic hammer, seen at the centre of the relief's composition, as a symbol of the battle against Titanic forces standing in the way between mankind and its spiritual home (Halink 2019). These forces had to be overcome before spiritual development was possible. Hence, the first part of the series can be interpreted as a representation of the pagan prehistory of (the white race of) humanity, when people still believed in the existence of many gods instead of just one. The human soul is shown in a state of chaos where physical strength is in command. The rather simplified stylistic execution, particularly in the modelling of the human figures, which some critics have perceived as crudeness resulting from a lack of skill, may then be understood to reflect this archaic content.

The second relief in the series presents a big turning point: the Babylonian Captivity. This is a highly significant episode in Jewish history and culture, and one that has been considered to have far-reaching impact on the development of Judaism. Schuré gives the people of Israel a particularly important role in the history of humanity because he saw them as the people who established monotheism and gave birth to Christianity. The people of Israel, therefore, form an indispensable link between the old and the new cycle, between the East and the West. The monotheistic idea, when understood correctly within its esoteric framework, holds the potential to unify all of humanity under the same God and under a single law. According to Schuré, this pure and fundamental doctrine is at the heart of both the Old and New Testaments, but it had become lost in the numerous editions and 
translations (Schuré 1888/1992: 152-3). The Babylonian Captivity is the event that begins the dissemination of the messianic idea. After that the initiates (or prophets) started to preach the arrival of the Messiah.

The third part, The Sermon on the Mount which is also called The Acceptance of Christianity presents the culmination of the journey: the arrival of Jesus. According to Schuré, the public life of Jesus was preceded by a long process of development and initiation, which he received from the Order of the Essenes (Schuré 1888/1992: 394-7). It is believed in many esoteric traditions that the distinct group of Jews called the Essenes had preserved the true meaning of the books of Moses, while elsewhere this secret knowledge had been lost since the Babylonian Captivity (see Churton 2005: 51-6; Hammer and Snoek 2006). Schuré explains that the Essenes taught Jesus the original, esoteric interpretation of the Book of Genesis, hidden under the seal of its symbolism, as well as the basic ideas of Orphic and Pythagorean doctrine, including that of the immortality of the soul. In a state of ecstasy, Jesus received a message from a heavenly voice that told him that it was his destiny to give back to the people the secret of life and immortality that they had once possessed but had then lost (Schuré 1888/1992: 394-7, 402-6).

In the Sermon on the Mount Jesus delivered the most important content of his public teaching through which he began his mission of establishing the Kingdom of Heaven on earth. It was widely held among Theosophists and other esoteric thinkers of the day that this public sermon also contained the esoteric core of his doctrine, but that this true meaning of Jesus's teaching had become distorted in the official formulations of established Christianity. According to this Theosophically oriented interpretation, Jesus appears as an initiated master whose teachings contain secret knowledge passed on through generations (see Kokkinen 2019: 222-35). The relief shows Jesus amidst his followers with one hand raised up towards the heavens above and the other one pointing down towards the earth: as above, so below. The spiritual realm unfolds itself in the souls of those who are listening: 'The Kingdom of Heaven is within you!' This is the message of love and forgiveness that he hands down to all humanity, but to his disciples he also gives a secret teaching that he has gained from the esoteric tradition. He delivers it in words that are veiled in double or triple meanings, and hence their true significance can only be grasped by those who have penetrated deeply into the esoteric traditions of India, Egypt and Greece. At the core of this is the basic esoteric doctrine according to which human beings are threefold: consisting of body, soul, and spirit. The spirit is immortal and indivisible, the body is perishable and divisible, and the soul forms a link between the two (Schuré 1888/1992: 393-411).

The esoteric meaning of the Resurrection is linked with this basic doctrine: 'It means the purification and regeneration of the sidereal, ethereal and fluidic body, which is the very organ of the soul and, to some extent, the vessel of the spirit. Through the inner development of the soul, the process of purification may begin already in this life, but for most people it is fulfilled only after death, and then only for those who in their life have aspired to righteousness and truth (Schuré 1888/ 1992: 452). When this universal message is given to the people, it is possible for those who accept it to start their journey towards the heavenly Kingdom; that is, their original home in the spiritual realm. Here it may be recalled that in the letter to Westermarck cited above, af Forselles talks about 'arriving at home in the Spirit World'. 


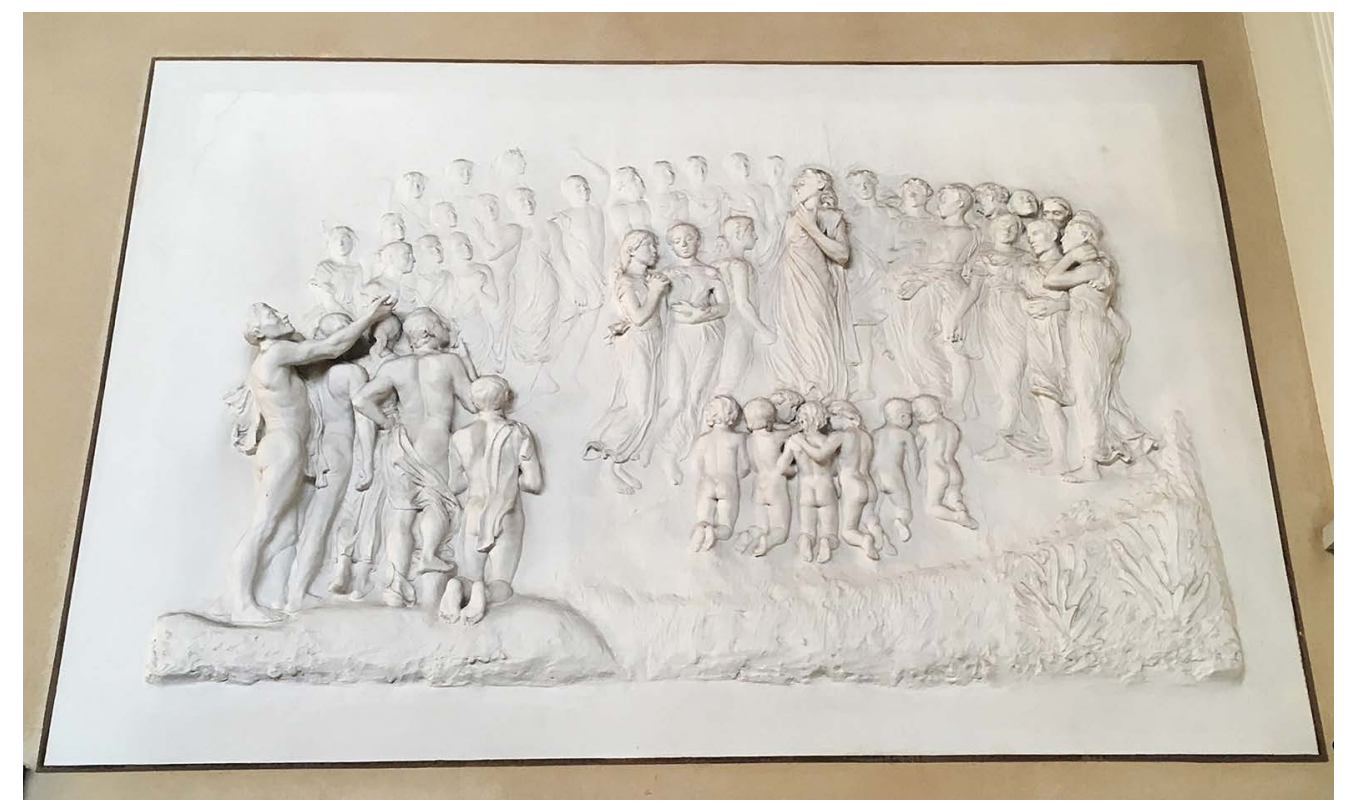

The Arrival Home, relief by Sigrid af Forselles in the organ gallery of Kallio Church.

Photo: Marja Lahelma.

The procession of the purified souls towards heaven is depicted in the fourth relief, The Homeward Journey. Solid earth disappears from underneath the feet of the men, women, and children who are guided by winged angels towards a higher plane. The compositional and iconographical elements bring to mind art-historical depictions of the Last Judgement and the resurrection of the dead. A particularly close reference can be found in a monumental work carried out by af Forselles's friend Magnus Enckell: the altarpiece fresco Resurrection (1907) in Tampere Cathedral, incidentally, also an Art Nouveau church building designed by Lars Sonck. The right-hand side of the fresco shows a blissful procession of the souls towards eternal life, while on the left-hand side the dead are crawling out of their graves. Like af Forselles's relief, the painting suggests a Biblical theme but at the same time resists a straightforwardly Christian interpretation. It is very likely that Enckell and af Forselles drew from the same sources of Italian Renaissance art, such as Luca Signorelli's fresco cycle in the Chapel of San Brizio in Orvieto Cathedral, which contains the subjects of dead rising from their graves as well as a procession of blessed souls (see Ojanperä 2020: 102).

In the final part of the series, The Arrival Home, the humans existing on the earthly plane have become aware of their heavenly origin - they have found the Kingdom of Heaven within their souls. These blessed, purified souls are shown to be on earth and in the heavens at the same time. At the centre of the composition stands the androgynous figure of Jesus, welcoming back home all those who have taken the final leap and made it through the difficult journey. A group of plump little children have gathered at his feet, three women with blissful expressions are positioned right in front of him, one of them almost touching him, and on the left bottom corner a muscular and robust nude man has raised his hand and is pointing it towards Jesus. The people are grouped around the central figure in an almost symmetrical, mandorla-like shape 
that also resembles a spiral turning towards the centre where Jesus stands. The composition of this last part is beautifully harmonious; it is the highlight of the series in an aesthetic sense as well as thematically.

\section{Conclusion: an impossible masterpiece?}

As a whole, the relief series The Development of the Human Soul has a musical quality which one would be able to appreciate better if it were possible to view all five parts together as they were intended. I believe that its narrative structure would play out like a symphony, starting from chaos and developing towards the harmonious grande finale. In its meaning, the series develops from materiality and physical strength towards spirituality and immateriality. The series presents a gradually unfolding spiritual evolution that corresponds with the development of an individual soul. In the late nineteenth-century esoteric context, this notion of spiritual evolution was connected to the modern scientific notion of evolution (Hanegraaff 1996: 462-82). Hence, despite its archaic stylisation, referring to Italian Renaissance sculpture, the relief series is also a very modern work of art that takes part in contemporary ideological debates connecting esotericism and modern science.

In the previous section, I carried out a rather intricate, part-by-part analysis of the relief series, reflecting on possible interpretations in an esoteric context. However, unlike Frosterus, I do not believe that there is an 'open sesame' to its meaning. As a Symbolist work of art, the series should not be understood as a puzzle or a riddle that needs to be solved. Rather, it should be seen as a platform for personal contemplation for the artist as well as for the viewer. As a total work of art that is deeply concerned with the most fundamental questions of humanity, the relief series ticks all the boxes of a Symbolist masterpiece. When Westermarck published her study in 1937 , Symbolist art was not greatly valued by art historians; it was perceived as nostalgic, overly literary, vaguely mystical, slightly decadent, and all in all a passing phase in the history of art. However, recent approaches towards the development of modern art have placed more emphasis on the significance of Symbolism, which is no longer perceived in terms of a style, but rather as a deeply philosophical approach to art and life that attaches itself to an entire world view - one that perhaps more often than not contains elements of esotericism (e.g. Facos and Mednick 2015; Lahelma 2014). From esoteric traditions the Symbolist artists could discover a theoretical basis for their understanding that art had a special role in the spiritual evolution of humanity. The relief series materialises the artist's personal process of seeking as a kind of initiation through which the secrets of life are revealed. This spiritual revelation corresponds to artistic experimentation and exploration in a manner that was not uncommon in the art of the period (see Kokkinen, in this issue). The journey through the history of the humankind is also a journey into the self. The viewer is invited to come along and discover the fundamental truths within her own soul.

In addition to being a Symbolist masterpiece, The Development of the Human Soul is also, as I suggested at the beginning of this article, an 'impossible masterpiece'. It reflects the kind of devotion to art in which art becomes completely inseparable from life in a creative process that continues for several years. Sigrid af Forselles had no commissioner for her monumental series; a fact which reflects her willingness to sacrifice everything for the sake of art. In her desire to create a monumental work 
she was probably inspired by her teacher Rodin, whose Gates of Hell was a similarly impossible project - although for Rodin, who already had a well-established reputation as an artist, such an ambitious attempt was not risky in the same sense as it was for af Forselles. Both works, however, are fundamentally about the promise of liberation for humanity, and they reflect an understanding of the work of art as a revelation of an idea that far surpasses the contours of the material object. Their purpose is not only to present the idea of revelation through personal contemplation, but to invite audiences to reflect on their personal feelings, thoughts and emotions, and thus to encourage the spiritual development of humanity. Rodin's sculpture was also long in the making, and it was not cast in bronze until after the artist's death. The art historian Hans Belting has explained that, in a way, the secret of Rodin's work's success lies precisely in its rejection of masterpiece status. In its incompleteness, The Gates of Hell has come to be viewed as one of the greatest achievements of modern art (Belting 2001: 216-24; Lahelma 2014: 237-40). There is, of course no way of knowing what would have happened to af Forselles and her relief series had she found a buyer willing to cast it in bronze and place it in some prestigious setting. However, as it is, we cannot think of its fate as anything but unfortunate. The current state of fragmentariness of The Development of the Human Soul is not the kind that would give it an aura of mystery, but rather the kind that pushes the work into oblivion.

It seems, then, that the incredible level of ambition that produced the relief series was also ultimately the cause of its failure. It became too large, in both its physical and spiritual proportions. In addition, there are, of course multiple, more mundane, reasons for its exclusion from the canon. Liisa Lindgren (2006) has discussed the question of the relief's marginalisation from the perspective of gender, which certainly is a significant factor. One may argue that as a monumental work made by a woman artist who at the time was relatively unknown, it was destined to receive little attention. Without active campaigning by her friends the reliefs may have been completely forgotten and eventually destroyed. Also, the formalist approach to modern art has meant that a sculptural work that reflects a Renaissance ideal has appeared nostalgic rather than modern, and without the esoteric contextualisation, the relief has been perceived as conventional in terms of both style and content, and therefore insignificant or uninteresting. Finally, the way that it is currently displayed and the fact that the first relief has been separated from the four parts installed in Kallio Church makes it very difficult to interpret the series as a whole. Neither its full meaning nor its visual effect can be experienced as they were intended. Moreover, the separation of the first part has made it possible to place the remaining parts rather unproblematically within a Christian context and hence the significance of the whole as an esoterically inspired work of art has been lost.

It may be claimed, of course, that an esoteric interpretation would only have served to further marginalise this unusual work of art. Yet, I would argue that in the Finnish art-historical context, it is not so much its esotericism that pushes The Development of the Human Soul into the margins, but rather its lack of any kind of nationalist sentiment. Lindgren (2006: 56) assumes that af Forselles's religious mysticism felt alien in comparison to the realistic and dynamic style of the leading sculptors of the day, Robert Stigell and Emil Wikström. She adds, moreover that 
the time period was full of political and nationalistic tensions. All this explains very well why Westermarck would insist on the realist quality of af Forselles's art. Yet, as I have argued elsewhere, Wikström was also deeply involved in the spiritual seeking of the day, and his Lönnrot Memorial, which celebrates the 1ooth anniversary of the birth of Elias Lönnrot, the composer of the Finnish 'national epic', The Kalevala, is full of esoteric symbolism (Lahelma 2020). However, because it has been so easy to interpret this monumental work as a reflection of nationalistic sentiment, its esoteric side has remained in the shadows. Sigrid af Forselles's art, on the other hand, attaches itself to a broad international context of esotericism and Symbolism - which is precisely what makes it so fascinating from today's perspective.

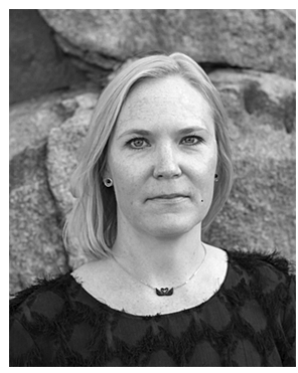

Dr Marja Lahelma is an art historian specialising in Nordic art around the year 1900. She received her $\mathrm{PhD}$ in 2014 and holds a title of docent in art history at the University of Helsinki. Lahelma has published works on Symbolist art, questions of the self and subjectivity, and on the relationship between art, science, and esotericism.

\section{Bibliography}

Ayral-Clause, Odile. 2002. Camille Claudel: A Life (New York: Harry N. Abrams).

Belting, Hans. 2001. The Invisible Masterpiece (London: Reaktion Books).

Bois, Jules. 1894. Les petites religions de Paris (Paris: Léon Chailley).

Churton, Tobias. 2005. Gnostic Philosophy: From Ancient Persia to Modern Times (Rochester: Inner Traditions).

-—2016. Occult Paris: The Lost Magic of the Belle Époque (Rochester: Inner Traditions).
Facos, Michelle, and Thor Mednick (eds.). 2015. The Symbolist Roots of Modern Art (Farnham: Ashgate).

Faivre, Antoine. 2006. 'Christian Theosophy', in History of Gnosis \& Western Esotericism, ed. Wouter J. Hanegraaff (Leiden: Brill), 258-67.

Fauser, Annegret. 2008. “"Wagnerism”: responses to Wagner in the music and the arts', in The Cambridge Companion to Wagner, ed. Thomas S. Grey (Cambridge University Press), 219-34.

Frosterus, Sigurd. 1908. 'Kvinnliga konstnärers andra utställning i Ateneum II. Fröken Sigrid af Forselles relief-cykel', Nya Pressen, 27.3.1908.

Friberg, Maikki [M. F.]. 1912. 'Suomalainen naiskuvanveistäjä, Naisten ääni, 2.11.1912.

Goodrick-Clarke, Nicholas. 2008. The Western Esoteric Traditions: A Historical Introduction (Oxford University Press).

Halink, Simon. 2019. 'The Quest of Gangleri: Theosophy and Old Norse mythology in Iceland, in Northern Myths, Modern Identities: The Nationalisation of Northern Mythologies since 180o, ed. Simon Halink (Leiden: Brill), 192-213.

Hammer, Olav, and Jan A. M. Snoek. 2006. 'Essenes, esoteric legends about', in History of Gnosis \& Western Esotericism, ed. Wouter J. Hanegraaff (Leiden: Brill), 340-3.

Hanegraaff, Wouter J. 1996. New Age Religion and Western Culture: Esotericism in the Mirror of Secular Thought (Leiden: Brill).

Hartikainen, Arja. 1994. 'Sigrid af Forselles ja reliefisarja "Ihmissielun kehitys", master's thesis, Dept. of Art History, University of Jyväskylä.

Herrick, James A. 2008. Scientific Mythologies: How Science and Science Fiction Forge New Religious Beliefs (Downers Grove, IL: Inter Varsity Press).

Huet, Anne-Laure. 2016. Madeleine Jouvray (1862-1935): une sculptrice au tournant du siècle, <https://dumas.ccsd.cnrs.fr/dumas$01670163>$ (accessed 15.1.2021).

Kihlman, Asta. 2018. Kolme tutkielmaa sukupuolesta. Identiteettipolitiikka Beda Stjernschantzin, Sigrid af Forsellesin ja Ellen Thesleffin taiteessa, $\mathrm{PhD}$ dissertation, Annales Universitatis Turkuensis, C 457 (University of Turku). 
Kokkinen, Nina. 2019. Totuudenetsijät. Vuosisadanvaihteen okkultuuri ja moderni henkisyys Akseli Gallen-Kallelan, Pekka Halosen ja Hugo Simbergin taiteessa, PhD dissertation, Annales Universitatis Turkuensis, C 469 (University of Turku).

Konttinen, Riitta. 2004. 'Forselles, Sigrid af', Kansallisbiografia-verkkojulkaisu, Studia Biographica, 4 (Helsinki: SKS), <https:// kansallisbiografia-fi.libproxy.helsinki.fi/ kansallisbiografia/henkilo/3362> (accessed 18.12.2020).

- 2008. 'Sigrid af Forselles (1860-1935)', in Naistaiteilijat Suomessa. Keskiajalta modernin murrokseen (Helsinki: Tammi), 374-81.

Lahelma, Marja. 2014. Ideal and Disintegration: Dynamics of the Self and Art at the Finde-Siècle, PhD dissertation (University of Helsinki).

- -2020. 'From nostalgia to where...? National romanticism, esotericism, and the "Golden Age of Finnish Art"', European Revivals: From Dreams of a Nation to Places of Transnational Exchange, FNG Research, 1 (Helsinki: Finnish National Gallery), 177-206.

Lindgren, Liisa. 2006. 'Sigrid Af Forselles ja naistaiteilijan demonit', in Keskellä marginaalia. Riitta Konttisen juhlakirja (Helsinki: Taidehistorian seura), 45-61.

- -2015. 'Sigrid af Forselles and Hilda Flodin, Rodin's Finnish students', in Rodin: Auguste Rodin (1840-1917) and the Nordic Countries, ed. Linda Hinners (Stockholm: Nationalmuseum), 143-51.

Ojanperä, Riitta. 2020. 'Resurrection', in Magnus Enckell, eds. Hanne Selkokari and Lene Wahlsten (Helsinki: Finnish National Gallery), 99-109.

Pilbeam, Pamela M. 2013. Saint-Simonians in Nineteenth-Century France: From Free Love to Algeria (New York: Palgrave Macmillan).

Pincus-Witten, Robert. 1968. Joséphin Peladan and the Salons de la Rose+Croix, $\mathrm{PhD}$ dissertation (University of Chicago).

Rilke, Rainer Maria. 1903. Auguste Rodin (Berlin: Greifenverlag).

Sarajas, Korte, Salme. 1966. Suomen varhaissymbolismi ja sen lähteet. Tutkielma Suomen maalaustaiteesta 1891-1895 (Helsinki: Otava).

Schuré, Édouard. 1888/1992. The Great Initiates: A Study of the Secret History of Religions (New York: SteinerBooks).
Wilkinson, Lynn R. 1996. The Dream of an Absolute Language: Emanuel Swedenborg \& French Literary Culture (Albany: State University of New York Press).

Westermarck, Helena. 1937. Tre Konstnärinnor: Fanny Churberg, Maria Wiik och Sigrid af Forselles (Helsingfors: Söderström \& C:O Förlagsktiebolag). 